BOGDÁN PÉTER

\title{
Ott vagyok otthon, ahol elfogadnak
}

Az individuumnak számtalan identitása lehet. Én elsősorban embernek érzem magam, s mint ember, elsősorban akkor érzem otthon (azaz jól) magam, ha elfogadó környezet vesz körül.

Ez az elfogadó közeg lehet a szük családom (édesanyám, nővérem és a gyermekei vagy a feleségem és rokonsága), de lehet a tágabb szociális szférát jelentő baráti köröm is.

A munkahelyeimen - eddigi életem során - szintén ott éreztem magam otthon, ahol a munkatársak feltétel nélkül elfogadtak emberként, s ez érvényes a széleskörü társadalmi környezetre is, azaz akkor érzem magam otthon, ha a romamagyar származásom roma szegmense miatt, illetve szakmai körökben az eszperantó nyelvtudásom miatt, nem diszkriminál senki.

Vagyis az otthonosság érzése számomra azt jelenti, hogy jól érzem magam a börömben azért, mert ember vagyok, $\mathrm{s}$ azért, mert az engem körülvevő környezet ezt szintén így gondolja, s ebböl adódóan nem okoz nekem (akármilyen eltérö jellemzőm miatt) lelki vagy fizikai sérüléseket.

Bikulturális romamagyar értelmiségiként természetesen kikerülhetetlen, hogy ne érezzem mindig otthon (azaz jól) magam, mert hátrányos megkülönböztetés ér a roma mivoltom miatt. Nem vagyok otthon azokban az üzletekben, ahol a biztonsági örök a rasszjegyeim miatt, majdnem szó szerint, a sarkamban loholnak. Nem vagyok otthon ott, ahol látványosan kapják magukhoz (az oldalukhoz görcsösen szorítva) a táskájukat az emberek a tömegközlekedési állomáshelyeken és jármüveken. Nem vagyok otthon ott, ahol lekezelően viselkednek velem, ahol durva, elutasító, agresszív retorikával találkozom, vagy akár meg is ütnek és számtalan más módon megaláznak a származásom roma része miatt, miközben magyar nyelv és irodalom szakos bölcsészként, középiskolai tanárként, újságíróként és doktori cím várományosaként az egyetemes magyar kultúra hordozója, letéteményese, átadója, közvetítője vagyok.

Nem vagyok otthon akkor sem, ha szakmai körökben diszkriminálnak (kinevetnek, lekezelően kritizálnak) azért, mert vállalom, hogy eszperantista vagyok, hogy felsőfokon beszélek egy olyan mesterséges nyelvet, amiről a közvélekedéssel ellentétben azt képzelem, hogy demokratikusabb, mint bármelyik más nyelv a világon, mert meggyőzött az a gondolat, hogy a zamenhofi nyelv nemzetnélkülisége

* A szerző oktatáskutató, a Társadalomtudományi Kutatóközpont Kisebbségkutató Intézet munkatársa. E-mail: Bogdan.Peter@tk.hu 
azt jelenti: az eszperantó mindenkié, és minden nyelvi közösségnek lehet a közvetítő nyelve, miközben meg tudja őrizni minden nemzet, nemzetiség és etnikum kultúráját is, annak köszönhetően, hogy az eszperantó senkinek sem az anyanyelve, senkinek sincs nyelvi elönye a másikkal szemben, a megértést nemzetközi relációban csak az befolyásolja, hogy ki mennyire és milyen szinten sajátította el.

Ha az otthonosság érzetét a ,jól érzem magam, elfogadnak” értelemben használom, akkor mindenképpen ki kell térni arra, hogy belföldön és külföldön hogyan élem meg a romamagyar identitásomat.

Az az előzőkből kiderült, hogy Magyarországon van példa arra, hogy elfogadnak romaként és magyarként is, bikulturális első generációs roma értelmiségiként is, s vannak, akik elutasítják azt, hogy a nemzet része vagyok, olyan lényként tekintenek rám, aki nem lehet kvalifikált, $\mathrm{s}$ mindenképpen alárendelt szerepben van, vagy akár alacsonyabb rendủ is a nem roma honfitársaihoz képest.

Az országhatárt átlépve ez a kettősség megszünik. Külföldön angol nyelven kommunikáló magyarként azonosítanak, amely minden „roma bélyeget” (ha úgy tetszik, akkor a C-betüt a homlokomról) eltávolít, de olyan is előfordul, hogy nyugati multietnikus, multikulturális társadalmakban teljesen természetesnek veszik, hogy indiai rasszjegyeim vannak, s nemes egyszerüséggel vagy franciaként, vagy olaszként vagy törökként azonosítanak, amely azonban nem jelent problémát, mert hozzá van szokva az adott ország domináns társadalmi rétege ahhoz, hogy rajtuk kívül él még az országukban számtalan kisebbség is.

Ez utóbbi adottság miatt - habár körülbelül 25-28 országban fordultam meg életemben - csak egyszer-egyszer fordult elö Göteborgban és Pozsonyban, hogy a rasszjegyeim miatt diszkrimináltak, vagyis bárhová mentem külföldre, feltétel nélkül elfogadtak, emberként, kedves turistaként kezeltek, akivel illet jól bánni.

Ez a külföldi attitüd bennem kialakított egyfajta kozmopolitizmust, amelynek eredményeképpen mindig otthon éreztem magam azokban az idegen országokban, ahol megfordultam, és igyekeztem, ha rövid időre is, némiképp integrálódni, amennyiben azonnal megpróbáltam kommunikálni az adott nemzet nyelvén, ami minden esetben pozitív visszhangra talált.

Bikulturális romamagyar értelmiségiként, tanárként, újságíróként, kutatóként reflektálnom kell arra is, hogy milyen romamagyar értelmiségiként úgy tanítani, írni, hogy általában csak roma témában szólalok meg vagy roma témákban kérik a segítségemet.

Mivel 41 éves vagyok, a ciganológia számtalan ágáról szereztem ismeretet és tudást, $\mathrm{s}$ az ezen témakörben való állandó mozgás jelent szintén egyfajta otthonosságot, mert a romamagyar értelmiségieken kívül olyan nem roma értelmiségiekkel is együtt dolgozom, akik - a romamagyar entellektüelekhez hasonlóan - szintén értik a „roma ügy” lényegét, problematikáját, azaz szakmailag felkészültek, erős 
tudásbeli háttérrel rendelkeznek, s nem fordulhat elő az, hogy etnikai alapon a munka során - bármilyen diszkrimináció érjen.

Ha össze kellene foglalni a gondolataimat, akkor azt mondanám: kozmopolita ember vagyok, aki bikulturális identitású, a hazájában szeretné maradéktalanul otthon érezni magát, megélni a bikulturális identitása minden pozitívumát, de erre a „maradéktalanságra” lehetősége eddig csak külföldön vagy hazai, illetve nemzetközi eszperantó rendezvényeken, közösségekben volt. 